\title{
Growth Traits and the Trade-Offs for Tree Species with Arbuscular Mycorrhizal Fungi in a Tropical Rain Forest Edge at Los Tuxtlas, Mexico
}

\author{
Juan Carlos Peña-Becerril, Javier Álvarez-Sánchez*, Guadalupe Barajas-Guzmán, \\ Ana María Quiroz-Ayala \\ Departamento de Ecología y Recursos Naturales, Facultad de Ciencias, Universidad Nacional Autónoma de \\ México, Ciudad Universitaria, Mexico City, México \\ Email: ${ }^{\text {javier.alvarez@ciencias.unam.mx }}$
}

Received 5 January 2015; accepted 22 January 2015; published 27 January 2015

Copyright (C) 2015 by authors and Scientific Research Publishing Inc.

This work is licensed under the Creative Commons Attribution International License (CC BY). http://creativecommons.org/licenses/by/4.0/

(c) (7)

\section{Abstract}

The effect of arbuscular mycorrhizal fungi on seedling growth across the rain forest-pasture edge has not received much attention. In a tropical rain forest in eastern Mexico, the seedlings of light demanding (Ficus insipida), nonsecondary light demanding (Lonchocarpus cruentus) and shade tolerant species (Nectandra ambigens, Coccoloba hondurensis) were grown and transplanted to a forest edge with three inoculation treatments (AM fungus spores and colonized roots, spores, and no inoculum). For all species, stem height, stem diameter, total dry weight, leaf area and net assimilation rate were higher in the pasture. Stem height, stem diameter and root/shoot were higher for $L$. cruentus, and leaf area ratio, specific leaf area and net assimilation rate were higher for $F$. insipida; the lowest values of almost all variables were recorded for $N$. ambigens. $L$. cruentus and $C$. hondurensis with mycorrhizae had the highest values for root/shoot and net assimilation rate, respectively. The lowest values of root/shoot and net assimilation rate were observed for nonlight-demanding species in the forest. There were clear trade-offs for the pioneer species between survival and growth, and in underground biomass allocation and assimilation for nonsecondary light demanding, but there was not for the shade-tolerant species.

\section{Keywords}

Arbuscular Mycorrhizal Fungi, Edge Forest, Tropical Trees, Trade-Offs, Tropical Rain Forest

\footnotetext{
${ }^{*}$ Corresponding author.
}

How to cite this paper: Peña-Becerril, J. C., Álvarez-Sánchez, J., Barajas-Guzmán, G., \& Quiroz-Ayala, A. M. (2015). Growth Traits and the Trade-Offs for Tree Species with Arbuscular Mycorrhizal Fungi in a Tropical Rain Forest Edge at Los Tuxtlas, Mexico. Open Journal of Forestry, 5, 181-194. http://dx.doi.org/10.4236/ojf.2015.52017 


\section{Introduction}

Deforestation is the main cause of vegetation loss in tropical ecosystems (Achard et al., 2002). In Los Tuxtlas, Veracruz, Mexico, human activities, which are the source of significant disturbance, include forest exploitation and clearing for crops and raising livestock; currently, the landscape is made up of fragmented rain forest, cultivated land, pasture and rain forest fragments in the process of secondary succession (“acahual”) (Guevara et al., 2004a).

Fragmentation creates an edge effect around the patches, which consists of microclimatic changes (Laurance, 2004), such as increased temperatures and soil that is under higher evaporative demand, as well as faster, more turbulent wind (Pohlman et al., 2007). These differences, which enhance growth and species recruitment (Benítez-Malvido \& Martínez-Ramos, 2003), generate changes in the vegetation structure and species composition around the edge (Harper et al., 2005). The establishment of tropical species is related to the dry mass of seed reserves (Bloor \& Grubb, 2003) and their abundance on the soil, a seed size-dependent trade-off between dispersal success and emergence-establishment success (Dalling \& Hubbell, 2002), germination type (Parolini et al., 2003), understory light heterogeneity (Montgomery \& Chazdon, 2002), growth responses to shade (Wright et al., 2010), and a trade-off between high-light growth and low-light mortality (Davies, 2001).

Mycorrhizal fungi and nitrogen fixing bacteria are among the most important components of soil microbiota (Jeffries et al., 2003). Changes in land use in tropical forest can lead to: a) the abundance of arbuscular mycorrhizal fungus (AMF) spores increasing in pastures (Picone, 2000); and b) the diversity of AMF fungi decreasing (Oehl et al., 2003), or staying the same (Picone, 2000). AMF can survive these changes owing to their high degree of resilience (Violi et al., 2008; Stürmer \& Siquiera, 2010). In the Los Tuxtlas forest, an increase in spore abundance in pastures and agroforestry sites was observed, but AMF diversity decreased with the loss of forest cover (Varela et al., 2009).

Efforts to facilitate the establishment of a long term functional tropical rain forest ecosystem must include the development of a native microbial community, particularly of the AMF that interact with the host tree species inhabiting the forest edge. AM fungi are widely represented in tropical ecosystems (Lovelock et al., 2003), and have a mutualist relationship with plant roots-improving survivorship, growth and plant reproduction (Sanderss et al., 1995). These fungi improve phosphorus absorption and make it available to plants (Allen, 1991; Smith \& Read, 2008); they affect the ability of plants to compete (Guadarrama et al., 2004) and play a determinant role in both regeneration and plant succession (Van der Heijden et al., 1998).

The effect of AM fungi on seedling growth has been analysed in dry tropical ecosystems (Allen et al., 2003), savannas (Cuenca et al., 2006), and tropical rain forest (Zangaro et al., 2005; Zangaro et al., 2007), but it has been poorly documented for the edges of the tropical rain forest, a key site for regeneration.

AM fungi have been found to favour biomass production in native species (Pouyú-Rojas \& Siqueira, 2000). However, recent studies in tropical rain forest have demonstrated that a plant's life history plays a very important role in its response to colonization by AM fungi: light demanding species have stronger growth responses to AM fungi than shade tolerant species do (Zangaro et al., 2000, 2005, 2007).

We designed this study because: a) there is no information about the effect of AM fungi on the seedling growth and establishment of trees growing at the edge of tropical rain forests; b) this analysis can provide information about the response of tropical trees to anthropogenic changes at the edges of tropical rain forest (Guevara et al., 2004a); c) the results will be useful for designing rain forest conservation and restoration programs. The objective of this study was to determine the effect of AM fungi on the growth of light demanding and shade tolerant species across the edge of a tropical rain forest.

\section{Materials Methods}

\subsection{Study Site}

The forest fragment (640 ha) where the study site is located, belongs to the coastal plains of the Gulf of Mexico in the southern region of the state of Veracruz between $18^{\circ} 00^{\prime}$ and $18^{\circ} 43^{\prime} \mathrm{N}$ latitude and from $94^{\circ} 40^{\prime}$ to $95^{\circ} 30^{\prime} \mathrm{W}$ longitude, covering an elevation of 195 to $500 \mathrm{~m}$ a.s.l. at the Los Tuxtlas Tropical Biology Station (LTTBS) run by the Universidad Nacional Autónoma de México (Figure 1).

The average annual temperature fluctuates between $24^{\circ} \mathrm{C}$ and $26^{\circ} \mathrm{C}$ and annual precipitation is 3000 to 4000 $\mathrm{mm}$. The climate is type A: warm and humid. In this region there are tropical cyclones and nortes (masses of cold air originating in the northern part of the continent) from November to February; the latter bring strong 


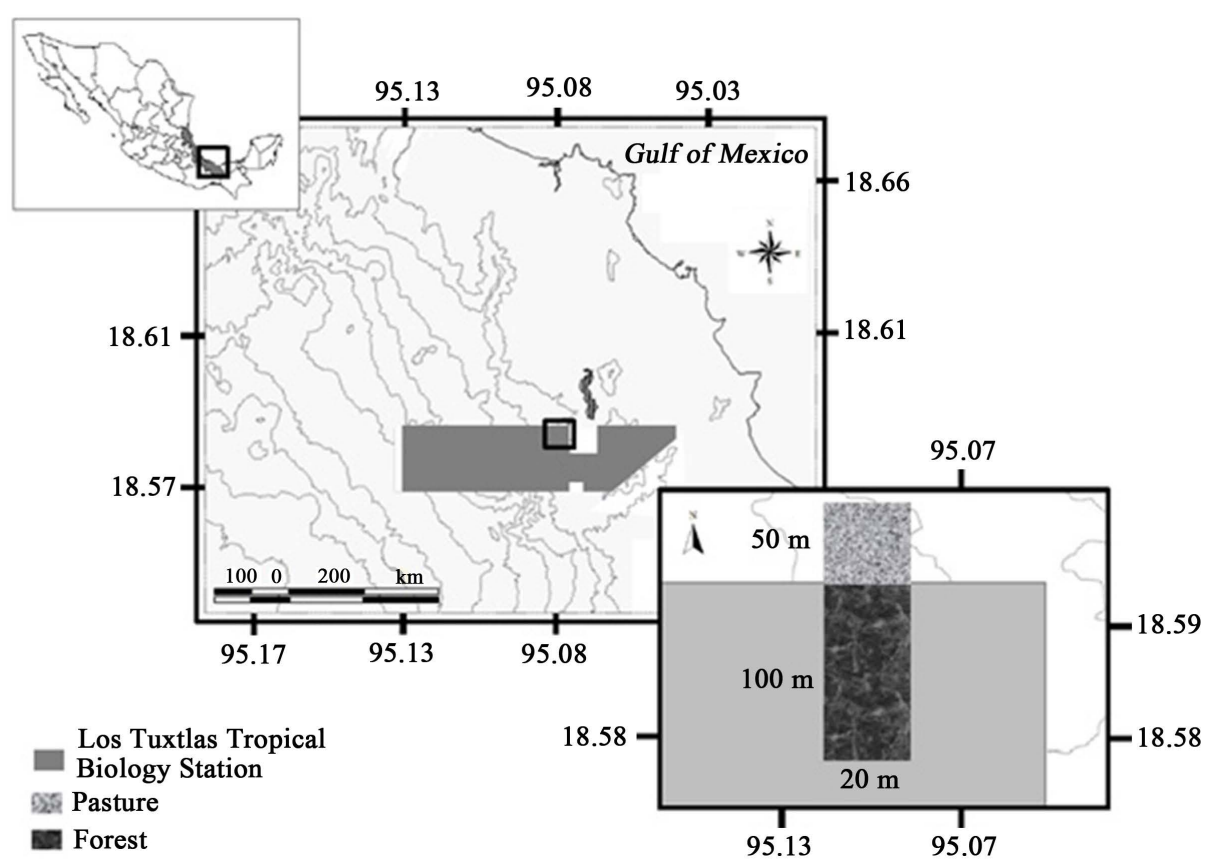

Figure 1. Location (degrees) of the study sites within the Los Tuxtlas Tropical Biology Station at Veracruz, Mexico, which is a tropical rain forest. The pasture site is surrounded by cattle pastures.

winds, lower temperatures and winter rain (Soto \& Gama, 1997).

The soil is greyish brown owing to iron oxides with a clayey-crumbly texture. Organic matter accumulates in the upper layers (from $1.64 \%$ to $6.48 \%$ ), where the $\mathrm{pH}$ varies from 5.3 to 6.7 . The soil has high concentrations of aluminium, calcium and alophans as well as total nitrogen and phosphorus (Flores-Delgadillo et al., 1999), but is very poor in available phosphorus $\left(1.8-3.3 \mathrm{mg} \cdot \mathrm{kg}^{-1}\right.$ ) (Escamilla, 2009). The soil in the study site is an andosol (Sommer-Cervantes et al., 2003).

The dominant vegetation is tropical rain forest (Castillo-Campos \& Laborde, 2004) with a canopy that reaches 30 to $35 \mathrm{~m}$; occasional larger $40 \mathrm{~m}$ individuals are observed.

\subsection{Study Species}

In this study we selected one light demanding (LD) tree species: Ficus insipida Willd. (Moraceae), one nonsecondary light demanding species (NSLD) Lonchocarpus cruentus Lundell (Fabaceae), and two shade tolerant (ST) tree species: Coccoloba hondurensis Lond. (Polygonaceae) and Nectandra ambigens (Blake) C. K. Allen (Lauraceae). The LD species we selected is part of the higher arboreal strata in secondary (disturbed) forest (Guariguata \& Ostertag, 2001). Our NSLD species can survive in primary or secondary forest, but needs high light during the first stage of growth; it is a common species in forest fragments (Arroyo-Rodríguez \& Mandujano, 2007) and very abundant on the seed bank beneath fig trees in pastures (Guevara et al., 2004b). The ST species are important to both the regeneration and the structure (canopy and arboreal higher strata) of the rain forest (Arroyo-Rodríguez \& Mandujano, 2007); like seedlings are in the group that accounts ca. 50\% according to the importance value index (Sánchez-Gallen, 2011). Coccoloba (Polygonaceae) has been reported with Ectomycorrhizal fungi in rainforest (Tedersoo et al., 2010), but inconsistencies in his response has been reported (Koele et al., 2012); we never saw seedlings with ectomycorrhizae structures.

\subsection{Germination, Inoculation and Transplantation}

Seeds were collected in January 2003, disinfected in a solution of 10\% sodium hypochlorite for 10 minutes and rinsed with tap water. Seeds were germinated in containers with vermiculite and perlite (3:1). The seedlings were then placed in plastic bags with vermiculite and sterile, sieved rain forest soil (3:1) that had been sterilized in an autoclave for one hour at $100^{\circ} \mathrm{C}$, cooled for 24 hours and the process repeated. 
To determine spore quantity ten $100 \mathrm{~g}$ soil samples were randomly collected from the primary rain forest in a section of the LTTBS. The spores were separated from the soil using the wet sifting and decanting method proposed by Gerdemann and Nicolson (1963), and modified by Daniels and Skipper (1982). The spores in the samples were then counted using a stereoscopic microscope $(5 \times)$ and we decided to use 150 spores per 200 g (dry weight) of soil to inoculate the seedlings (Álvarez-Sánchez et al., 2009). The root inoculum was obtained from the soil from which the spores were obtained, and $2.72 \mathrm{~g}$ were used (wet weight). To determine the percentage of inoculation, we used the technique of staining of Phillips and Hayman (1970); the initial percentage of inoculation initial was the $10.3 \%$.

The plants were inoculated in the planting hole to each cultivation bag at the end of September 2003 and kept in the greenhouse for 70 days before transplanting. Several samples of uninoculated treatments were carefully checked at the beginning of the experiment and showed no evidence of colonization. There were three levels of AM fungus inoculation: AM fungus spores and colonized roots (SR), spore inoculation (S), and no inoculum considered as the control group (M-). In December 2003, 10 seedlings were harvested from each treatment to obtain data for time zero.

The transplant site (rain forest-pasture edge) is located in the northern section of the LTTBS, at $18^{\circ} 35^{\prime} 12.7^{\prime \prime} \mathrm{N}$ lat. and $95^{\circ} 04^{\prime} 40.6^{\prime \prime} \mathrm{W}$ long. with a $68^{\circ}$ north-eastern exposure and an elevation of $253 \mathrm{~m}$ a.s.l. This location was cleared for livestock use in 1976, high yield estrella grass was planted and Tordon ${ }^{\circledR}$ herbicide was applied every eight months until the beginning of this experiment. The pasture site was six months old at the beginning of the experiment. The soil and environmental characteristics for the transplant site are given in Table 1.

A $150 \times 20 \mathrm{~m}$ transect was set up perpendicular to the rain forest edge and covered three sites: pasture (0 - 50 $\mathrm{m})$, forest edge $(50-100 \mathrm{~m})$ and closed canopy of the rain forest (forest interior, $100-150 \mathrm{~m}$ ). In December 2003, for each species 20 seedlings from each treatment were systematically transplanted to each site for a total of 180 seedlings per species, and 720 in total. The seedlings were randomly planted $2 \mathrm{~m}$ apart along parallel lines. It was necessary to cut back the grass and weeds in the pasture every two or three months.

Three factors were analysed: site, species and inoculation with AM fungi (three levels). At the end of the experiment, 10 plants of each species were selected per treatment from each plot and harvested for growth analysis; all plants were used for the survivorship analysis. The percentage of colonization was determined for each treatment too. The AMF responsiveness was calculated as the difference between the biomass of the shoot of inoculated and uninoculated plants according to Plenchette et al. (1983).

\subsection{Variables}

Growth variables (Hunt, 1982) were used to evaluate seedling response. Leaf area (LA) (measured with a Digital Image Analysis System, version 1.06), dry stem (S), dry root (R) and total dry weight (TDW) (after drying in an oven at $70^{\circ} \mathrm{C}$ for 72 hours) were recorded for the first harvest in December 2003. Stem diameter (SD) at five $\mathrm{cm}$ from the ground and stem height ( $\mathrm{SH}$ ) were measured in the field every month thereafter. After 240 days in the field the species were harvested S, R and TDW and LA were measured. Root-shoot ratio (R/S), leaf area ratio (LAR), specific leaf area (SLA) and net assimilation rate (NAR) were also calculated (Hunt, 1982).

Table 1. Environmental and soil characteristics along a forest-pasture gradient in the Los Tuxtlas tropical rain forest ( ${ }^{1}$ Escamilla, 2009, ${ }^{2}$ Nuñez-Castillo \& Álvarez-Sánchez unpubl. data, ${ }^{3}$ Sánchez-Gallen et al. unpubl. data).

\begin{tabular}{|c|c|c|c|c|}
\hline & & Forest interior & Forest edge & Pasture \\
\hline & Texture & Sandy clay & Clay & Sandy clay \\
\hline & $\mathrm{pH}$ & 5.9 & 5.5 & 5.4 \\
\hline \multirow[t]{4}{*}{ Soil $^{1,3}$} & $\mathrm{CEC}\left(\mathrm{cmol}(+) \mathrm{kg}^{-1}\right)$ & 48 & 18 & 22 \\
\hline & P Olsen $\left(\mathrm{mg} \cdot \mathrm{kg}^{-1}\right)$ & 19 & 1.8 & 3.3 \\
\hline & Organic C (\%) & 5 & 3.4 & 3.1 \\
\hline & Light $\left(\mathrm{mmol}^{-1}\right)$ & $1-30$ & $30-500$ & $200-1200$ \\
\hline \multirow[t]{2}{*}{ Environment $^{2}$} & Average temperature (Min-Max, ${ }^{\circ} \mathrm{C}$ ) & $16-28$ & $15-29$ & $25-33$ \\
\hline & Relative humidity (\%) & $60-100$ & $50-100$ & $71-96$ \\
\hline
\end{tabular}




\subsection{Data Analysis}

An ANCOVA was used to compare the differences between the three factors: species, site, and AMF inoculation. The data for time zero were used as covariates. TDW and LA were log-transformed, and R/S and SLA were arcsine transformed to normalize the distribution (Zar, 2009).

\section{Results}

An average of $12 \%$ total colonization by AM fungi was observed at the end of the experiment (Peña et al., unpubl. data) (Table 2). In the greenhouse, all species showed a negative responsiveness for spore treatment, except for N. ambigens. F. insipida presented only positive values in the forest edge for SR and S treatments, while L. cruentus and C. hondurensis had positive values in the forest interior and forest edge for the same treatments; responsiveness of $N$. ambigens was negative in all treatments and sites, except for SR treatment in the forest interior (Table 3).

Table 2. Colonization by AM fungi. AMF spores and colonized roots (SR), spore inoculation (S), and no inoculum as the control (M-).

\begin{tabular}{|c|c|c|c|}
\hline Treatment & Hyphae (\%) & Vesicles (\%) & Total (\%) \\
\hline \multicolumn{4}{|c|}{ Ficus insipida } \\
\hline SR & 6.8 & 0.0 & 6.8 \\
\hline $\mathrm{S}$ & 8.8 & 0.0 & 8.8 \\
\hline M- & 5.9 & 0.0 & 5.9 \\
\hline \multicolumn{4}{|c|}{ Lonchocarpus cruentus } \\
\hline SR & 9.8 & 3.0 & 11.1 \\
\hline $\mathrm{S}$ & 18.9 & 6.9 & 23.3 \\
\hline M- & 13.3 & 6.2 & 13.8 \\
\hline \multicolumn{4}{|c|}{ Coccoloba hondurensis } \\
\hline SR & 4.6 & 0.4 & 4.6 \\
\hline $\mathrm{S}$ & 5.7 & 1.0 & 5.8 \\
\hline M- & 1.7 & 0.1 & 1.7 \\
\hline \multicolumn{4}{|c|}{ Nectandra ambigens } \\
\hline SR & 13.5 & 0.0 & 13.5 \\
\hline $\mathrm{S}$ & 25.4 & 0.0 & 25.4 \\
\hline M- & 23.3 & 0.0 & 23.5 \\
\hline
\end{tabular}

Table 3. Mean responsiveness values of arbuscular mycorrhizal fungi (AMF) according to (Plenchette et al., 1983) for treatments in greenhouse and transplant sites. AMF spores and colonized roots (SR), spore inoculation (S), and no inoculum as the control (M-; right columns); see text.

\begin{tabular}{ccccc}
\hline & & & Sites \\
\hline Treatment & Greenhouse & Forest interior & Forest edge & Pasture \\
\hline SR & 34.43 & Ficus insipida & -43.86 \\
S & -24.22 & -9.92 & 38.63 & -53.32 \\
& & -48.09 & 33.97 & -16.00 \\
SR & 8.02 & Lonchocarpus cruentus & & 8.15 \\
S & -17.66 & 53.95 & 39.68 & 14.89 \\
SR & 39.2 & 59.05 & 48.86 & -4.06 \\
S & -34.32 & Coccoloba hondurensis & 29.43 & -112.26 \\
SR & & 39.43 & 14.06 & -28.82 \\
S & 9.85 & Nectandra ambigens & -63.66 & -15.57 \\
\hline
\end{tabular}




\subsection{Growth Analysis}

SH, SD, TDW, LA and NAR were significantly different between sites $\left(\mathrm{F}_{(2,143)}=211.9,256.5,200.3,100.5\right.$ and 278.4, respectively; in all cases $p<0.0001$ ), the open site (pasture) was different from the edge and forest interior, but the latter two did not differ. The general trend for these five variables was to low values (and even negative in the case of NAR) at the edge and under the closed canopy, and was three to 13-fold higher (depending on the variable) in the pasture (Figure 2).

For R/S, LAR and SLA the trend was reversed, with the highest significant values recorded under the forest interior and at the forest edge. The lowest values were recorded in the pasture (Figure 3), but under the closed canopy and at the edge were only 1.3 to 1.6 times greater in than in the open site.
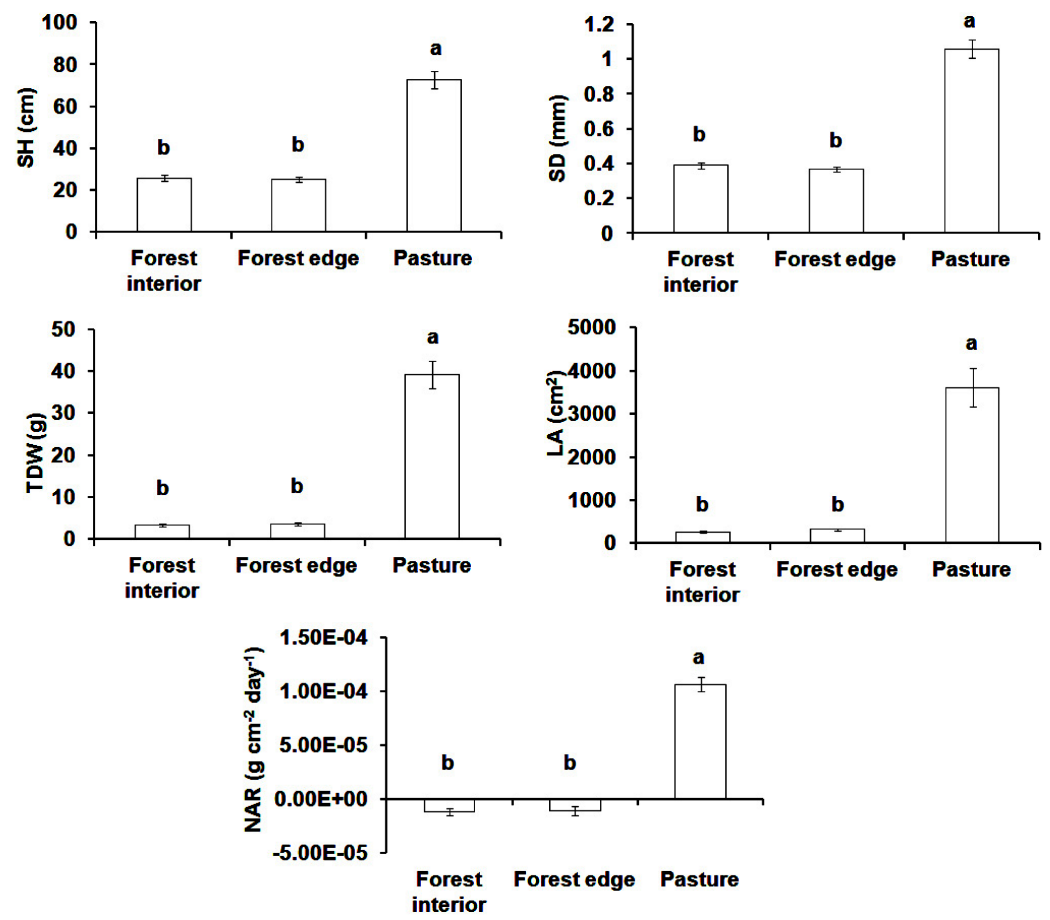

Figure 2. Differences between sites for SH (stem height), SD (stem diameter), TDW (total dry weight), LA (leaf area) and NAR (net assimilation rate) (mean \pm SE). Different letters indicate significant differences according to Tukey's test.
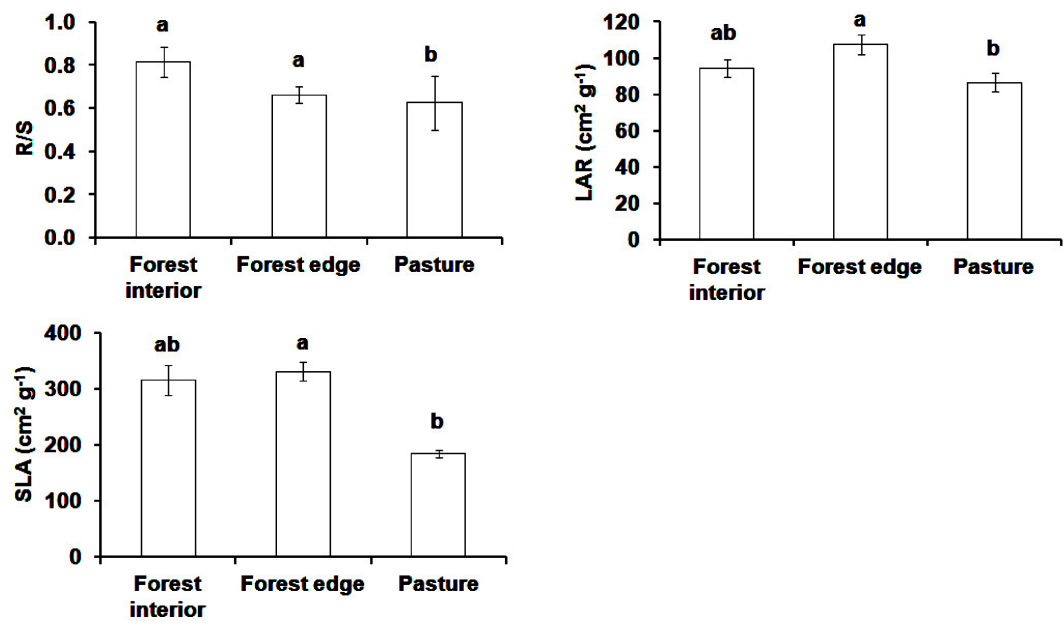

Figure 3. Differences between sites for: R/S (root/shoot), LAR (leaf area ratio) and SLA (specific leaf area) (mean $\pm \mathrm{SE}$ ). Different letters indicate significant differences according to Tukey’s test. 


\subsection{Differences between Species}

In a first global analysis (without treatments), there were significant differences among species in stem height, diameter, R/S, LAR, SLA and NAR $\left(\mathrm{F}_{(3,143)}=41.0,48.6,19.7,5.6,13.8\right.$ and 44.1, respectively; in all cases $p<$ 0.01) (Table 4). L. cruentus (ST) had the highest values for stem height, diameter and R/S, and F. insipida (LD) values were the highest for LAR and SLA. N. ambigens (ST) had lower and significantly different values for four of the six variables (Table 4).

\subsection{Species-Treatment Interaction}

In the species-treatment interaction only $\mathrm{R} / \mathrm{S}$ and NAR were significant $\left(\mathrm{F}_{(6,143)}=4.1\right.$ and 2.9 , respectively; $p<$ 0.05). The lowest value of $\mathrm{R} / \mathrm{S}$ was recorded for $C$. hondurensis in the spore treatment (S), and the highest was recorded with $L$. cruentus in the same treatment (Table 5). The lowest NAR value was recorded for N. ambigens in the spores and roots treatment (SR), and the highest for C. hondurensis in the same treatment (Table 5).

Table 4. Results for the growth variables measured (mean \pm SE): SH: stem height; SD: stem diameter; R/S: root/shoot; LAR: leaf area ratio; SLA: specific leaf area; NAR: net assimilation rate. Different letters indicate significant differences according to Tukey's test.

\begin{tabular}{|c|c|c|c|c|}
\hline \multirow[b]{2}{*}{ Variable } & \multicolumn{4}{|c|}{ Species } \\
\hline & Ficus insipida & Lonchocarpus cruentus & Coccoloba hondurensis & Nectandra ambigens \\
\hline $\mathrm{SH}(\mathrm{cm})$ & $46.75 \pm 33.15 b$ & $62.46 \pm 49.93 \mathrm{a}$ & $19.32 \pm 14.86 \mathrm{c}$ & $36.53 \pm 19.24 \mathrm{c}$ \\
\hline $\mathrm{SD}(\mathrm{mm})$ & $0.55 \pm 0.40 \mathrm{~b}$ & $0.92 \pm 0.71 \mathrm{a}$ & $0.45 \pm 0.28 \mathrm{c}$ & $0.50 \pm 0.22 \mathrm{c}$ \\
\hline $\mathrm{R} / \mathrm{S}$ & $0.58 \pm 0.23 \mathrm{~b}$ & $1.17 \pm 1.74 \mathrm{a}$ & $0.42 \pm 0.20 \mathrm{c}$ & $0.63 \pm 0.36 \mathrm{~b}$ \\
\hline $\operatorname{LAR}\left(\mathrm{cm}^{2} \cdot \mathrm{g}^{-1}\right)$ & $124.93 \pm 57.03 \mathrm{a}$ & $116.39 \pm 73.45 b$ & $85.50 \pm 36.42 b$ & $57.14 \pm 19.91 \mathrm{c}$ \\
\hline $\operatorname{SLA}\left(\mathrm{cm}^{2} \cdot \mathrm{g}^{-1}\right)$ & $453.42 \pm 169.28 \mathrm{a}$ & $275.88 \pm 318.04 b$ & $211.65 \pm 86.95 b$ & $180.11 \pm 38.86 \mathrm{c}$ \\
\hline NAR $\left(\mathrm{g} \cdot \mathrm{cm}^{-2} \cdot\right.$ day $\left.^{-1}\right)$ & $5.02 \mathrm{E}-05 \pm 6.93 \mathrm{E}-05 \mathrm{a}$ & $0.19 \mathrm{E}-05 \pm 5.70 \mathrm{E}-05 \mathrm{~b}$ & $5.89 \mathrm{E}-05 \pm 7.84 \mathrm{E}-05 \mathrm{a}$ & $-3.58 \mathrm{E}-05 \pm 5.90 \mathrm{E}-05 \mathrm{~b}$ \\
\hline
\end{tabular}

Table 5. Results of the species-treatment interaction for root/shoot (R/S) and net assimilation rate (NAR) (mean \pm SE). Different letters indicate significant differences according to Tukey’s test. SR: spores and colonized roots; S: spore inoculation; M-: no inoculum.

\begin{tabular}{|c|c|c|}
\hline Treatment & $\mathrm{R} / \mathrm{S}$ & NAR $\left(\mathrm{g} \cdot \mathrm{cm}^{-2} \cdot \mathrm{day}^{-1}\right)$ \\
\hline \multicolumn{3}{|c|}{ Ficus insipida } \\
\hline SR & $0.52 \pm 0.16 \mathrm{bc}$ & $5.54 \mathrm{E}-05 \pm 7.53 \mathrm{E}-05 \mathrm{a}$ \\
\hline $\mathrm{S}$ & $0.65 \pm 0.28 \mathrm{bc}$ & $3.77 \mathrm{E}-05 \pm 5.42 \mathrm{E}-05 \mathrm{abc}$ \\
\hline M- & $0.57 \pm 0.23 \mathrm{bc}$ & $5.77 \mathrm{E}-05 \pm 7.69 \mathrm{E}-05 \mathrm{a}$ \\
\hline \multicolumn{3}{|c|}{ Lonchocarpus cruentus } \\
\hline SR & $1.09 \pm 1.07 \mathrm{a}$ & $0.13 \mathrm{E}-05 \pm 4.66 \mathrm{E}-05 \mathrm{~cd}$ \\
\hline $\mathrm{S}$ & $1.32 \pm 2.68 \mathrm{abc}$ & $1.09 \mathrm{E}-05 \pm 6.08 \mathrm{E}-05 \mathrm{bcd}$ \\
\hline M- & $1.10 \pm 0.94 \mathrm{a}$ & $-0.64 \mathrm{E}-05 \pm 6.29 \mathrm{E}-05 \mathrm{~d}$ \\
\hline \multicolumn{3}{|c|}{ Coccoloba hondurensis } \\
\hline SR & $0.43 \pm 0.20 \mathrm{c}$ & $6.78 \mathrm{E}-05 \pm 7.91 \mathrm{E}-05 \mathrm{a}$ \\
\hline $\mathrm{S}$ & $0.40 \pm 0.20 \mathrm{c}$ & $6.21 \mathrm{E}-05 \pm 8.28 \mathrm{E}-05 \mathrm{a}$ \\
\hline M- & $0.43 \pm 0.21 b c$ & $4.68 \mathrm{E}-05 \pm 7.42 \mathrm{E}-05 \mathrm{ab}$ \\
\hline \multicolumn{3}{|c|}{ Nectandra ambigens } \\
\hline SR & $0.69 \pm 0.34 \mathrm{ab}$ & $-1.90 \mathrm{E}-05 \pm 8.46 \mathrm{E}-05 \mathrm{~d}$ \\
\hline $\mathrm{S}$ & $0.66 \pm 0.38 \mathrm{bc}$ & $1.67 \mathrm{E}-05 \pm 8.15 \mathrm{E}-05 \mathrm{bcd}$ \\
\hline M- & $0.53 \pm 0.24 \mathrm{bc}$ & $0.10 \mathrm{E}-05 \pm 7.85 \mathrm{E}-05 \mathrm{~cd}$ \\
\hline
\end{tabular}




\subsection{Species-Site Interaction}

The species-site interaction was significant for R/S, LAR, SLA and NAR $\left(F_{(6,143)}=4.2,7.5,7.2\right.$ and 3.5, respectively; in all cases $p<0.05$ ) (Table 6). It is particularly interesting that $L$. cruentus had the highest values of R/S and the lowest for NAR at the forest interior and forest edge, respectively. In all three environments $N$. ambigens had lower values of LAR and SLA, whereas F. insipida had higher values than other species for these variables in combination with all environments, and had the highest values of LAR and SLA at the forest edge. C. hondurensis in combination with the pasture had low values of R/S, LAR and SLA, and the highest value of NAR (Table 6). The three-way interaction was significant only for $\mathrm{R} / \mathrm{S}\left(\mathrm{F}_{(12,143)}=3.44 p<0.001\right)$.

\section{Discussion}

Tropical species have a wide range of responses to variations in environmental conditions. Light is a limiting resource for plant establishment (Kitajima \& Fenner, 2000), and is an essential resource for light demanding (LD) and nonsecondary light demanding (NSLD) species (Arroyo-Rodríguez \& Mandujano, 2007).

\subsection{Site Differences}

Stem height (SH), stem diameter (SD), total dry weight (TDW) and net assimilation rate (NAR) were different between sites: 5 to 13-fold higher in the pasture (depending on the variable), indicating that the reduced light availability and higher humidity exert a negative effect for species in the forest interior. The root/shoot ratio (R/S), leaf area rate (LAR) and specific leaf area (SLA) were lowest in the pasture because of the higher light levels.

For stem height and diameter results the highest values were mainly observed for light demanding species and in the pasture. When a gap opens in the forest, the increase in the photosynthetic rates and $\mathrm{C}$ fixation is reflected in increased biomass and growth (relative growth rate, RGR) (Rincón \& Huante, 1993). The availability of light in the pasture therefore allowed the plants to grow almost continuously. The slow growth of species in the rain forest interior can be explained by the low light availability in the understory, which is reflected in the negative values of the growth rates (Kitajima, 1994), as occurred with NAR in our study.

Table 6. Results of the species-site interaction for root/shoot (R/S), leaf area ratio (LAR), specific leaf area (SLA) and net assimilation rate (NAR) (mean \pm SE). Different letters indicate significant differences according to Tukey's test. FI: forest interior; FE: forest edge; P: pasture.

\begin{tabular}{|c|c|c|c|c|}
\hline Site & $\mathrm{R} / \mathrm{S}$ & $\operatorname{LAR}\left(\mathrm{cm}^{2} \cdot \mathrm{g}^{-1}\right)$ & $\operatorname{SLA}\left(\mathrm{cm}^{2} \cdot \mathrm{g}^{-1}\right)$ & NAR $\left(\mathrm{g} \cdot \mathrm{cm}^{-2} \cdot\right.$ day $\left.^{-1}\right)$ \\
\hline \multicolumn{5}{|c|}{ Ficus insipida } \\
\hline FI & $0.63 \pm 0.22$ bcd & $137.07 \pm 60.29 \mathrm{ab}$ & $529.37 \pm 125.46 \mathrm{a}$ & $0.80 \mathrm{E}-05 \pm 2.15 \mathrm{E}-05 \mathrm{c}$ \\
\hline $\mathrm{FE}$ & $0.64 \pm 0.27$ bcd & $153.72 \pm 53.17 \mathrm{a}$ & $555.49 \pm 139.83 \mathrm{a}$ & $1.11 \mathrm{E}-05 \pm 1.84 \mathrm{E}-05 \mathrm{c}$ \\
\hline $\mathrm{P}$ & $0.47 \pm 0.16 \mathrm{~cd}$ & $83.99 \pm 27.88 \mathrm{~cd}$ & $275.39 \pm 55.82$ bcde & $13.17 \mathrm{E}-05 \pm 6.06 \mathrm{E}-05 \mathrm{a}$ \\
\hline \multicolumn{5}{|c|}{ Lonchocarpus cruentus } \\
\hline FI & $1.29 \pm 1.31 \mathrm{ab}$ & $90.70 \pm 48.80 \mathrm{~cd}$ & $301.32 \pm 510.25$ cde & $-2.18 \mathrm{E}-05 \pm 2.63 \mathrm{E}-05 \mathrm{cde}$ \\
\hline $\mathrm{FE}$ & $1.00 \pm 0.64 \mathrm{ab}$ & $108.97 \pm 81.63$ bcd & $335.64 \pm 177.93$ bcde & $-3.55 \mathrm{E}-05 \pm 3.53 \mathrm{E}-05 \mathrm{e}$ \\
\hline $\mathrm{P}$ & $1.22 \pm 2.66 \mathrm{abcd}$ & $149.49 \pm 75.10 \mathrm{ab}$ & $190.68 \pm 80.82 \mathrm{~cd}$ & $6.31 \mathrm{E}-05 \pm 4.64 \mathrm{E}-05 \mathrm{~b}$ \\
\hline \multicolumn{5}{|c|}{ Coccoloba hondurensis } \\
\hline FI & $0.51 \pm 0.24 \mathrm{~cd}$ & $89.76 \pm 39.13$ bcd & $255.34 \pm 91.56$ abcd & $0.51 \mathrm{E}-05 \pm 2.97 \mathrm{E}-05 \mathrm{~cd}$ \\
\hline $\mathrm{FE}$ & $0.41 \pm 0.13 \mathrm{e}$ & $106.87 \pm 31.71 \mathrm{abc}$ & $253.13 \pm 57.01 \mathrm{abc}$ & $1.24 \mathrm{E}-05 \pm 2.47 \mathrm{E}-05 \mathrm{c}$ \\
\hline $\mathrm{P}$ & $0.34 \pm 0.19 \mathrm{e}$ & $59.88 \pm 19.06 \mathrm{~cd}$ & $126.48 \pm 17.66$ de & $15.91 \mathrm{E}-05 \pm 4.19 \mathrm{E}-05 \mathrm{a}$ \\
\hline \multicolumn{5}{|c|}{ Nectandra ambigens } \\
\hline FI & $0.82 \pm 0.42 \mathrm{bc}$ & $59.14 \pm 19.95 \mathrm{~cd}$ & $180.15 \pm 28.18$ cde & $-3.99 \mathrm{E}-05 \pm 5.15 \mathrm{E}-05 \mathrm{e}$ \\
\hline $\mathrm{FE}$ & $0.60 \pm 0.23 \mathrm{~cd}$ & $59.91 \pm 20.20 \mathrm{~cd}$ & $180.06 \pm 47.73$ de & $-3.17 \mathrm{E}-05 \pm 6.63 \mathrm{E}-05 \mathrm{de}$ \\
\hline $\mathrm{P}$ & $0.47 \pm 0.19 \mathrm{~cd}$ & $52.35 \pm 18.08 \mathrm{~d}$ & $145.37 \pm 33.94 \mathrm{e}$ & $7.08 \mathrm{E}-05 \pm 7.68 \mathrm{E}-05 \mathrm{~b}$ \\
\hline
\end{tabular}


One of the life history traits of shade tolerant species is biomass allocation to the aboveground part of the plant rather than to the root system. This result in low root-shoot values under both shade and light conditions (Gehring, 2003) and concurs with the results of our study: the plants that grew in the pasture had lower R/S ratios than those in the rain forest interior.

\subsection{Species Differences}

With the exception of TDW, all variables were significantly different between species. F. insipida (LD) had the highest values in LAR, SLA and NAR; the results for the latter two variables were contrary to what would be expected for a LD species. LAR and NAR values reflect the fact that LD intercepts more light per unit leaf biomass; this has also been observed by Selaya et al. (2008) and by Cai et al. (2008). The capacity of some tropical species to modify leaf area in response to varying light intensity allows plants to adjust to a wide range of light environments (Rincón \& Huante, 1993) and confirms that light is the most important resource controlling seedling responses (Cai et al., 2008).

Leaf characteristics (size and thickness) are of great importance in carbon assimilation, water relations and the energy balance of the plant (Ackerly et al., 2002). The SLA is a very important variable that lets us evaluate this (Wright et al., 2005), and is determinant for seedling growth. As SLA values increase, there is an increase in the light absorption area and $\mathrm{CO}_{2}$ per unit of leaf biomass (Lambers \& Poorter, 1992). In addition, the SLA is considered a key factor for explaining the differences in growth among species (Poorter \& van der Werf, 1998).

F. insipida has higher values of SLA, but on the edge and in the pasture rather than in the forest as might be expected. Studies of this indicate that light demanding species are very plastic for this variable, while shade tolerant species are not likely to exhibit such a plastic response, since large leaves increase the possibility of being consumed by herbivores and leaf material is difficult to replace in limited light environments (Walters \& Reich, 1999). Shade tolerant seedlings can live in the understory growing slowly for many years, and then grow more quickly in response to increased light availability when a gap opens up (Kitajima, 1994). However, the results of ST species in our study are contradictory; according to Rozendaal et al. (2006), shade-tolerant species that experience consistently low light levels and experience large ontogenetic changes in irradiance during their life cycle had high plasticity. So it is not easy for us to generalize, as Saldaña-Acosta et al. (2008) also found. In locations with high insolation, plants have a lower leaf area per biomass unit to reduce water loss from transpiration (Turner, 2001), and this was observed to occur in N. ambigens and C. hondurensis (low LAR). These species have slow growth rates and thick, long-lived leaves (with a low leaf area/total plant biomass ratio). This response is part of the plant's adaptation to shady conditions in the rain forest interior where leaf area is maximized to maintain carbon supply. The relationship between leaf mass and leaf area is related to toughness, longevity, and chemical defenses against attack by herbivores and pathogens. ST plants allocate more to plant defense than to growth, and as a consequence they have slower growth rates than LD species do (Strauss-Debenedetti \& Bazzaz, 1996). However, F. insipida (LD) had the highest LAR values in the rain forest locations, indicating greater leaf area per plant weight, and this could be associated with an increased efficiency in light energy absorption (Kitajima \& Fenner, 2000). Álvarez-Sánchez et al. (2007) observed higher SLA and NAR values for Piper auritum (light demanding) and Rollinia jimenezii (shade tolerant) in the presence of AM fungi, and even observed significant differences in RGR for Heliocarpus appendiculatus, H. donnell-smithii, and F. yoponensis (Álvarez-Sánchez et al., 2009). We found significant differences in LAR for Ficus.

NAR is an indirect measure of photosynthetic activity (Rodríguez, 2006) and these values were lower in Nectandra too. Previous studies have demonstrated changes in the response of N. ambigens (Álvarez-Sánchez et al., 2009); in our study $N$. ambigens did not exhibit changes in the individual response because it always had the lowest NAR and R/S. N. ambigens is very interesting because it had negative NAR values in the rain forest interior; an environment that probably inhibited photosynthesis and thus, carbon absorption.

Shade tolerant species have thin leaves (higher SLA) and rapidly produce new leaves during the early life stages, while LD species have thicker leaves and a smaller SLA (Saldaña-Acosta et al., 2008). SLA has been found to decrease as humidity and the availability of resources decreases, and this functional attribute is negatively correlated with the longevity of the leaves and their assimilation rates (Reich et al., 1997). However, ST species may also have leaves with lower SLA than those of LD species (Reich et al., 2003), as we observed along the Los Tuxtlas pasture-forest gradient. 
As an ST species, the results for $N$. ambigens are consistent with respect to growth, because it had the lowest values for most of the variables (R/S, LAR, NAR and SLA). The species-site interaction results for this species confirm this because they were significantly lower than those for other species. L. cruentus again exhibited atypical behavior, with the greatest height relative to ST, but also for R/S values. The results of its species-site interaction are consistent with the highest values at the edge and in the closed forest canopy (as a possible ST species), but it had the lowest NAR, which seems to confirm a NSLD strategy.

The results of the species-treatment interaction are interesting because for $L$. cruentus it is precisely the R/S ratio that is reinforced by the presence of AM fungi (i.e., it had the highest values), suggesting that the species effect is greater, and that AMF improves the performance of this species and its growth possibilities in competitive environments. In fact, this species has not been observed under natural conditions inside the forest. The trade-off is different in F. insipida: AMF improves growth rather than survivorship (Álvarez-Sánchez et al., unpublished data). In a study of seven fragments of rain forest, Sánchez-Gallen (2011) found only two seedlings of L. cruentus, although Martínez-Garza et al. (2005) reported it to be a mid-canopy species. Guevara et al. (2004b) classified it as a primary forest tree, and it has been reported by Arroyo-Rodríguez et al. (2009) in sites with low levels of deforestation. It is obviously sensitive to disturbance and competition, but a strategy of biomass accumulation in the belowground biomass supported by AMF inoculation could help this species to remain in these sites.

C. hondurensis is another interesting species with respect to the species-treatment and species-site interactions. In the first case, AMF treatments increased NAR and R/S values. As an ST species $C$. hondurensis physiologically maximizes the leaf area per unit of total biomass produced in shady forest conditions (the trade-off is in the same as that of L. cruentus), and this also suggests a greater efficiency in the accumulation of belowground resources. For the second interaction, the results are consistent because we observed the lowest values of R/S, LAR and SLA for C. hondurensis in the pasture. However, with $N$. ambigens it is clear that there is no trade-off because it had the lowest NAR values in the absence of AMF, which indicates that it is not benefiting from AM fungi.

Pouyú-Rojas and Siqueira (2000) found that the biomass and height of plants inoculated with AM fungi were greater than those of plants that had not been inoculated, while Allen et al. (2003) found that for native plants inoculated with AM fungi and then transplanted to a disturbed area, height, canopy cover, biomass, SD and RGR were greater than for those without AM fungi. For the ST species, which establish during the later stages of regeneration, mycorrhizae seem to be more important to establishment than to survivorship. The opposite occurs for LD species for which AMF were very important to survivorship. This has also been observed for light demanding species in previous studies carried out in the Los Tuxtlas forest (Guadarrama et al., 2004).

In terms of forest regeneration, AMF improve the capacity of LD species to colonize disturbed and open sites, and AMF increase the ability of ST species to grow efficiently under shade. This was consistent with AMF responsiveness for LD species, because was higher in forest edge, in comparison to ST (in particular N. ambigens) which had negative values; Zangaro et al. (2007) reported that responsiveness depends of the successional status of species. The strategies of species whose seedlings regularly formed associations with AMF and those that did not were found to have similar rates of growth and survivorship (Gehring \& Connell, 2006), suggesting that mycorrhizal and nonmycorrhizal strategies were of equal importance to nutrient uptake in these forests. This seems to be different from the Los Tuxtlas forest, where the trade-offs observed in the presence of AMF suggests that light and P limitation (Flores-Delgadillo et al., 1999) could explain this.

The effects of AM fungi on their host plants, on plant community diversity, and the relationship of AM fungi to the nutrient cycle and soil stability (Rilling, 2004), in addition to our results about the performance trade-offs with AM fungi, all provide solid reasons for suggesting they be used more systematically in restoration projects.

\section{Conclusion}

It is clear that the response to inoculation with AMF depends on plant life stories traits. In our study, shade-tolerant showed no clear or not had any response, as happened in $N$. ambigens. However, the response tended to be more favorable in the case of the pioneers and the nonsecondary light demanding species. This favorable response to AMF inoculation, in addition with the ability to produce a trade-off, would increase the chances of success in the colonization of disturbed environments for these species. 


\section{Acknowledgements}

We are grateful to the Programa de Apoyo a Proyectos de Investigación e Innovación Tecnológica (PAPIIT) of the Universidad Nacional Autónoma de México (UNAM Grant IN-235402), the Secretaría de Medio Ambiente y Recursos Naturales-Consejo Nacional de Ciencia y Tecnología (Grant 2002-c01-668), and the Packard Foundation. We thank Patricia Guadarrama and Irene Sánchez-Gallen for their help with the statistical analysis of the data. We are grateful to Dulce M. Moreno-Miranda for map drawing, to Braulio Gómez and to the authorities and workers of the Los Tuxtlas Tropical Biology Station (UNAM) for their help with the field work.

\section{References}

Achard, F., Eva, H. D., Stibig, H.-J., Mayaux, P., Gallego, J., Richards, T., \& Malingreau, J. P. (2002). Determination of Deforestation Rates of the World's Humid Tropical Forests. Science, 297, 999-1002. http://dx.doi.org/10.1126/science.1070656

Ackerly, D. D., Knight, C. A., Weiss, S. B., \& Barton, K. (2002). Leaf Size, Specific Leaf Area and Microhabitat Distribution of Chaparral Woody Plants: Contrasting Patterns in Species Level and Community Level Analyses. Oecologia, 130, 449-457. http://dx.doi.org/10.1007/s004420100805

Allen, E. B., Allen, M. F., Egerton-Warburton, L., Corkidi, L., \& Gómez-Pompa, A. (2003). Impacts of Early- and LateSeral Mycorrhizae during Restoration in Seasonal Tropical Forest, Mexico. Ecological Applications, 13, 1701-1717. http://dx.doi.org/10.1890/02-5309

Allen, M. F. (1991). The Ecology of Mycorrhizae. Cambridge: Cambridge University Press.

Álvarez-Sánchez, J., Guadarrama, P., Sánchez-Gallen, I., \& Olivera, D. (2007). Restauración de ambientes deteriorados derivados de la selva húmeda: El uso de los hongos micorrizógenos arbusculares. Boletín de la Sociedad Botánica de México, 80, 59-68.

Álvarez-Sánchez, J., Sánchez-Gallen, I., \& Guadarrama, P. (2009). Ch. 18: Analysis of Ecophysiological Traits of Tropical rain Forest Seedlings under Arbuscular Mycorrhization: Implications in Ecological Restoration. In A. Varma, \& A. C. Kharkwal (Eds.), Symbiotic Fungi: Principles and Practice (pp. 293-305). Berlin: Springer-Verlag. http://dx.doi.org/10.1007/978-3-540-95894-9_18

Arroyo-Rodríguez, V., \& Mandujano, S. (2007). Ch. 7: Efectos de la fragmentación sobre la composición y la estructura de un bosque tropical lluvioso mexicano. In C. A. Harvey, \& J. C. Sáenz (Eds.), Evaluación y conservación de biodiversidad en paisajes fragmentados de Mesoamérica (pp. 179-196). Costa Rica: Instituto Nacional de Biodiversidad (INBio).

Arroyo-Rodríguez, V., Dunn, J. C., Benítez-Malvido, J., \& Mandujano, S. (2009). Angiosperms, Los Tuxtlas Biosphere Reserve, Veracruz, Mexico. Check List, Journal of Species Lists and Distribution, 5, 787-799. http://www.checklist.org.br

Benítez-Malvido, J., \& Martínez-Ramos, M. (2003). Influence of Edge Exposure on Tree Seedling Species Recruitment in Tropical Rain Forest Fragments. Biotropica, 35, 530-541. http://dx.doi.org/10.1111/j.1744-7429.2003.tb00609.x

Cai, Z. Q., Poorter, L., Han, Q., \& Bongers, F. (2008). Effects of Light and Nutrients on Seedlings of Tropical Bauhinia Lianas and Trees. Tree Physiology, 28, 1277-1285. http://dx.doi.org/10.1093/treephys/28.8.1277

Castillo-Campos, G., \& Laborde, J. (2004). Ch. 12: La vegetación. In S. Guevara, J. Laborde, \& G. Sánchez-Ríos (Eds.), Los Tuxtlas, el paisaje de la sierra (pp. 41-55). Xalapa: Instituto de Ecología, A.C.

Cuenca, G., Lovera, M., Fajardo, L., \& Meneses, E. (2006). Efecto de las micorrizas arbusculares sobre el crecimiento y supervivencia de dos especies nativas de la gran sabana, al transplantarlas a un área degradada. Acta Científica Venezolana, 57, 42-48.

Dalling, J. W., \& Hubbell, S. P. (2002). Seed Size, Growth Rate and Gap Microsite Conditions as Determinants of Recruitment Success for Pioneer Species. Journal of Ecology, 90, 557-568. http://dx.doi.org/10.1046/j.1365-2745.2002.00695.x

Daniels, B., \& Skipper, H. (1982). Methods for the Recovery and Quantitative Estimation of Propagules from Soil. In N. Schenck (Ed.), Methods and Principles of Mycorrhiza Research (pp. 29-37). Minnesota: American Society for Phytopathology.

Davies, S. J. (2001). Tree Mortality and Growth in 11 Sympatric Macaranga Species in Borneo. Ecology, 82, 920-932. http://dx.doi.org/10.1890/0012-9658(2001)082[0920:TMAGIS]2.0.CO;2

Escamilla, H. N. (2009). Características del suelo en un borde selva-potrero en los Tuxtlas, Veracruz. Bachelor Thesis, México City: Universidad Nacional Autónoma de México.

Flores-Delgadillo, L., Sommer-Cervantes, I., Alcalá-Martínez, J. R., \& Álvarez-Sánchez, J. (1999). Estudio morfogenético de algunos suelos de la región de los Tuxtlas, Veracruz, México. Revista Mexicana de Ciencias Geológicas, 16, 81-88. 
Gehring, C. A. (2003). Growth Responses to Arbuscular Mycorrhizae by Rain Forest Seedlings Vary with Light Intensity and Tree Species. Plant Ecology, 167, 127-139. http://dx.doi.org/10.1023/A:1023989610773

Gehring, C. A., \& Connell, J. H. (2006). Arbuscular Mycorrhizal Fungi in the Tree Seedlings of Two Australian Rain Forests: Occurrence, Colonization, and Relationships with Plant Performance. Mycorrhiza, 16, 89-98. http://dx.doi.org/10.1007/s00572-005-0018-5

Gerdemann, J. W., \& Nicolson, T. H. (1963). Spores of Mycorrhizal Endogone Species Extracted from Soil by Wet Sieving and Decanting. Transactions of the British Mycological Society, 46, 235-244. http://dx.doi.org/10.1016/S0007-1536(63)80079-0

Guadarrama, P., Álvarez-Sánchez, J., \& Briones, O. (2004). Seedling Growth of Two Pioneer Tropical Tree Species in Competition: The Role of Arbuscular Mycorrhizae. Euphytica, 138, 113-121. http://dx.doi.org/10.1023/B:EUPH.0000046797.42632.6b

Guariguata, M., \& Ostertag, R. (2001). Neotropical Secondary Forest Succssesion: Changes in Structural and Functional Characteristics. Forest Ecology and Management, 148, 185-206. http://dx.doi.org/10.1016/S0378-1127(00)00535-1

Guevara, S., Laborde, J., \& Sánchez-Ríos, G. (2004a). Ch. 5: La fragmentación. In S. Guevara, J. Laborde, \& G. SánchezRíos (Eds.), Los Tuxtlas, el paisaje de la sierra (pp. 111-134). Xalapa: Instituto de Ecología, A.C.

Guevara, S., Laborde, J., \& Sánchez-Ríos, G. (2004b). Rain Forest Regeneration beneath the Canopy of Fig Trees Isolated in Pastures of Los Tuxtlas, Mexico. Biotropica, 36, 99-108.

Harper, K. A., Macdonald, A. E., Burton, P. J., Jiquan, C., Brosofske, K. D., Saunders, S. C. et al. (2005). Edge Influence on Forest Structure and Composition in Fragmented Landscapes. Conservation Biology, 19, 768-782. http://dx.doi.org/10.1111/j.1523-1739.2005.00045.x

Hunt, R. (1982). Plant Growth Analysis. London: Natural Environment Research Council.

Jeffries, P., Gianinazzi, S., Perotto, S., Turnau, K., \& Barea, J. M. (2003). The Contribution of Arbuscular Mycorrhizal Fungi in Sustainable Maintenance of Plant Health and Soil Fertility. Biology and Fertility of Soils, 37, 1-16.

Kitajima, K, \& Fenner, M. (2000). Ecology of Seedling Regeneration. In M. Fenner (Ed.), Seeds: The Ecology of Regeneration in Plant Communities (pp. 331-359). London: CAB Publishing. http://dx.doi.org/10.1079/9780851994321.0331

Kitajima, K. (1994). Relative Importance of Photosynthetic Traits and Allocation Patterns as Correlates of Seedling Shade Tolerance of 13 Tropical Trees. Oecologia, 98, 419-428. http://dx.doi.org/10.1007/BF00324232

Koele, N., Dickie, I. A., Oleksyn, J., Richardson, S. J., \& Reich, P. B. (2012). No Globally Consistent Effect of Ectomycorrhizal Status on Foliar Traits. New Phytologist, 196, 845-852. http://dx.doi.org/10.1111/j.1469-8137.2012.04297.x

Lambers, H., \& Poorter, H. (1992). Inherent Variation in Growth Rate between Higher Plants: A Search for Physiological Causes and Ecological Consequences. Advances in Ecological Research, 23, 188-261. http://dx.doi.org/10.1016/S0065-2504(08)60148-8

Laurance, W. F. (2004). Forest-Climate Interactions in Fragmented Tropical Landscapes. Philosophical Transactions: Biological Sciences, 359, 345-352. http://dx.doi.org/10.1098/rstb.2003.1430

Lovelock, C. E., Andersen, K., \& Morton, J. B. (2003). Arbuscular Mycorrhizal Communities in Tropical Forest Are Affected by Host Tree Species and Environment. Oecologia, 135, 268-279.

Martínez-Garza, C., Peña, V., Ricker, M., Campos, A., \& Howe, H. F. (2005). Restoring Tropical Biodiversity: Leaf Traits Predict Growth and Survivorship of Late-Successional Trees in Early-Successional Environments. Forest Ecology and Management, 217, 365-379. http://dx.doi.org/10.1016/j.foreco.2005.07.001

Montgomery, R. A., \& Chazdon, R. L. (2002). Light Gradient Partitioning by Tropical Tree Seedlings in the Absence of Canopy Gaps. Oecologia, 131, 165-174. http://dx.doi.org/10.1007/s00442-002-0872-1

Oehl, F., Sieverding, E., Ineichen, K., Mäder, P., Boller, T., \& Wiemken, A. (2003). Impact of Land Use Intensity on the Species Diversity of Arbuscular Mycorrhizal Fungi in Agroecosystems of Central Europe. Applied and Environmental Microbiology, 69, 2816-2824. http://dx.doi.org/10.1128/AEM.69.5.2816-2824.2003

Parolin, P., Ferreira, L. V., \& Junk, W. J. (2003). Germination Characteristics and Establishment of Trees from Central Amazonian Flood Plains. Tropical Ecology, 44, 157-169.

Phillips, J. M., \& Hayman, D. S. (1970). Improved Procedures for Clearing Roots and Staining Parasitic and Vesicualr-Arbuscular Mycorrhizal Fungi for Rapid Assessment of Infection. Transactions of the British Mycological Society, 55, 158161. http://dx.doi.org/10.1016/S0007-1536(70)80110-3

Picone, C. (2000). Diversity and Abundance of Arbuscular-Mycorrhizal Fungus Spores in Tropical Forest and Pasture. Biotropica, 32, 734-750. http://dx.doi.org/10.1646/0006-3606(2000)032[0734:DAAOAM]2.0.CO;2

Plenchette, C., Fortin, J. A., \& Furlan, V. (1983). Growth Response of Several Plants Species to Mycorrhiza in a Soil of Moderate P-Fertility. Plant and Soil, 70, 191-209, http://dx.doi.org/10.1007/BF02374781 
Pohlman, C. L., Turton, S. M., \& Goosem, M. (2007). Edge Effects of Linear Canopy Openings on Tropical Rain Forest Understory Microclimate. Biotropica, 39, 62-71. http://dx.doi.org/10.1111/j.1744-7429.2006.00238.x

Poorter, H., \& Van Der Werf, A. (1998). Is Inherent Variation in RGR Determined by LAR at Low Irradiance and by NAR at High Irradiance? A Review of Herbaceous Species. In H. Lambers, H. Poorter, M. M. I., \& M. Van Vuuren (Eds.), Inherent Variation in Plant Growth. Physiological Mechanisms and Ecological Consequences (pp. 309-336). Leiden, AH: Backhuys Publishers.

Pouyú-Rojas, E., \& Siqueira, J. O. (2000). Micorriza arbuscular e fertilização do solo no desenvolvimento pós-transplante de mudas de sete espécies florestais. Pesquisa Agropecuária Brasileira, 35, 103-114. http://dx.doi.org/10.1590/S0100-204X2000000100013

Reich, P. B., Walters, M. B., \& Ellsworth, D. S. (1997). From Tropics to Tundra: Global Convergence in Plant Functioning. Proceedings of the National Academy of Sciences of the United States of America, 94, 13730-13734. http://dx.doi.org/10.1073/pnas.94.25.13730

Reich, P. B., Wright, I. J., Cavender-Bares, J., Craine, J. M., Oleksyn, J., Westoby, M., \& Walters, M. B. (2003). The Evolution of Plant Functional Variation: Traits, Spectra, and Strategies. International Journal of Plant Sciences, 164, 143-164. http://dx.doi.org/10.1086/374368

Rilling, M. C. (2004). Arbuscular Mycorrhizae and Terrestrial Ecosystem Processes. Ecology Letters, 7, 740-754. http://dx.doi.org/10.1111/j.1461-0248.2004.00620.x

Rincón, E., \& Huante, P. (1993). Growth Responses of Tropical Deciduous Tree Seedlings to Contrasting Light Conditions. Trees, 7, 202-207. http://dx.doi.org/10.1007/BF00202074

Rodríguez, J. (2006). Efectos de la defoliación inducida sobre el crecimiento de tres arbustos ribereños de la Sierra tarahumara bajo condiciones de crecimiento en rizotrón. Master Thesis, México City: Universidad Nacional Autónoma de México.

Rozendaal, D. M. A., Hurtado, V. H., \& Poorter, L. (2006). Plasticity in Leaf Traits of 38 Tropical Tree Species in Response to Light: Relationships with Light Demand and Adult Stature. Functional Ecology, 20, 207-216. http://dx.doi.org/10.1111/j.1365-2435.2006.01105.x

Saldaña-Acosta, A., Meave, J. A., Paz, H., Sánchez-Velásquez, L. R., Villaseñor, J. L., \& Martínez-Ramos, M. (2008). Variation of Functional Traits in Trees from a Biogeographically Complex Mexican Cloud Forest. Acta Oecologica, 34, 111121. http://dx.doi.org/10.1016/j.actao.2008.04.006

Sánchez-Gallen, I. (2011). Análisis de la comunidad de plántulas, en relación con la de hongos micorrizógenos arbusculares, en fragmentos de vegetación remanente de una selva húmeda. Ph.D. Thesis, México City: Universidad Nacional Autónoma de México.

Sanderss, I. R., Koide, R. T., \& Shumway, D. L. (1995). Community-Level Interactions between Plants and Vesicular-Arbuscular Mycorrhizal Fungi. In A. Varma, \& B. Hock (Eds.), Mycorrhiza: Structure, Function, Molecular Biology and Biotechnology (pp. 607-625). Berlin: Springer-Verlag. http://dx.doi.org/10.1007/978-3-662-08897-5_26

Selaya, N. G., Oomen, R. J., Netten, J. J. C., Werger, M. J. A., \& Anten, N. P. R. (2008). Biomass Allocation and Leaf Life Span in Relation to Light Interception by Tropical Forest Plants during the First Years of Secondary Succession. Journal of Ecology, 96, 1211-1221. http://dx.doi.org/10.1111/j.1365-2745.2008.01441.X

Smith, S. E., \& Read, D. J. (2008). Mycorrhizal Symbiosis. San Diego, CA: Academic Press.

Sommer-Cervantes, I., Flores-Delgadillo, L., \& Gutiérrez-Ruiz, M. (2003). Ch. 1: Caracterización de los suelos de la Estación de Biología Tropical Los Tuxtlas. In J. Álvarez-Sánchez, \& E. Naranjo-García (Eds.), Ecología del suelo en la selva tropical húmeda de México (pp. 17-67). Xalapa: Instituto de Ecología, A.C.

Soto, M., \& Gama, L. (1997). Ch. 2: Climas. In S. E. González, R. Dirzo, \& R. C. Vogt (Eds.), Historia natural de Los Tuxtlas. Comisión Nacional para el Conocimiento y Uso de la Biodiversidad (pp. 7-23). México City: Instituto de Biología, Instituto de Ecología, UNAM.

Strauss-Debenedetti, S., \& Bazzaz, F. A. (1996). Photosynthetic Characteristics of Tropical Trees along Successional Gradients. In S. S. Mulkey, R. L. Chazdon, \& A. P. Smith (Eds.), Tropical Forest Plant Ecophysiology (pp. 162-186). New York: Chapman \& Hall Press. http://dx.doi.org/10.1007/978-1-4613-1163-8_6

Stürmer, S. L., \& Siqueira, J. O. (2010). Species Richness and Spore Abundance of Arbuscular Mycorrhizal Fungi across Distinct Land Uses in Western Brazilian Amazon. Mycorrhiza, 21, 255-267. http://dx.doi.org/10.1007/s00572-010-0330-6

Tedersoo, L, Sadam, A., Zambrano, M., Valencia, R., \& Bahram, M. (2010). Low Diversity and High Host Preference of Ectomycorrhizal Fungi in Western Amazonia, a Neotropical Biodiversity Hotspot. The ISME Journal, 4, 465-471. http://dx.doi.org/10.1038/ismej.2009.131

Turner, I. M. (2001). The Ecology of Trees in the Tropical Rain Forest. Cambridge: Cambridge University Press. http://dx.doi.org/10.1017/CBO9780511542206 
Van der Heijden, M. G. A., Klironomos, J. N., Ursic, M., Moutoglis, P., Streitwolf-Engel, R., Boller, T. et al. (1998). Mycorrhizal Fungal Diversity Determines Plant Biodiversity, Ecosystem Variability and Productivity. Nature, 396, 69-72. http://dx.doi.org/10.1038/23932

Varela, L., Trejo, D., Álvarez-Sánchez, J., Barois, I., Amora-Lazcano, E., Guadarrama, P. et al. (2009). Ch. 6: Land Use and Diversity of Arbuscular Mycorrhizal Fungi in Mexican Tropical Ecosystems: Preliminary Results. In I. Barois, E. J. Huising, P. Okoth, D. Trejo, \& M. de los Santos (Eds.), Below-Ground Biodiversity in Sierra Santa Marta, Los Tuxtlas, Veracruz, Mexico (pp. 99-112). Xalapa: Instituto de Ecología, A.C.

Violi, H. A., Barrientos-Priego, A. F., Wright, S. G., Escamilla-Prado, E., Morton, J. B., Menge, J. A., \& Lovatt, C. J. (2008). Disturbance Changes Arbuscular Mycorrhizal Fungal Phenology and Soil Glomalin Concentrations but Not Fungal Spore Composition in Montane Rain Forest in Veracruz and Chiapas, Mexico. Forest Ecology and Management, 254, $276-290$. http://dx.doi.org/10.1016/j.foreco.2007.08.016

Walters, M. B., \& Reich, P. B. (1999). Low-Light Carbon Balance and Shade Tolerance in the Seedlings of Woody Plants: Do Winter Deciduous and Broad-Leaved Evergreen Species Differ? New Phytologist, 143, 143-154. http://dx.doi.org/10.1046/j.1469-8137.1999.00425.x

Wright, I. J., Reich, P. B., Cornelissen, J. H. C., Falster, D. S., Garnier, E., Hikosaka, K. et al. (2005). Assessing the Generality of Global Leaf Trait Relationships. New Phytologist, 166, 485-496. http://dx.doi.org/10.1111/j.1469-8137.2005.01349.x

Wright, J. S., Kitajima, K., Kraft, N. J. B., Reich, P. B., Wright, I. J., Bunker, D. E. et al. (2010). Functional Traits and the Growth-Mortality Trade-Off in Tropical Trees. Ecology, 91, 3364-3674. http://dx.doi.org/10.1890/09-2335.1

Zangaro, W., Bononi, V. L., \& Trufen, S. B. (2000). Mycorrhizal Dependency, Inoculum Potential and Habitat Preference of Native Woody Species in South Brazil. Journal of Tropical Ecology, 16, 603-622. http://dx.doi.org/10.1017/S0266467400001607

Zangaro, W., Nishidate, F. R., Camargo, F. R. S., Romagnoli, G. G., \& Vandressen, J. (2005). Relationships among Arbuscular Mycorrhizas, Root Morphology and Seedling Growth of Tropical Native Woody Species in Southern Brazil. Journal of Tropical Ecology, 21, 529-540. http://dx.doi.org/10.1017/S0266467405002555

Zangaro, W., Nishidate, F. R., Vandressen, J., Andrade, G., \& Nogueira, M. A. (2007). Root Mycorrhizal Colonization and Plant Responsiveness Are Related to Root Plasticity, Soil Fertility and Successional Status of Native Woody Species in Southern Brazil. Journal of Tropical Ecology, 23, 53-62. http://dx.doi.org/10.1017/S0266467406003713

Zar, J. H. (2009). Biostatistical Analysis (5th ed.). Englewoods Cliffs, NJ: Prentice Hall Inc. 
Scientific Research Publishing (SCIRP) is one of the largest Open Access journal publishers. It is currently publishing more than 200 open access, online, peer-reviewed journals covering a wide range of academic disciplines. SCIRP serves the worldwide academic communities and contributes to the progress and application of science with its publication.

Other selected journals from SCIRP are listed as below. Submit your manuscript to us via either submit@scirp.org or Online Submission Portal.
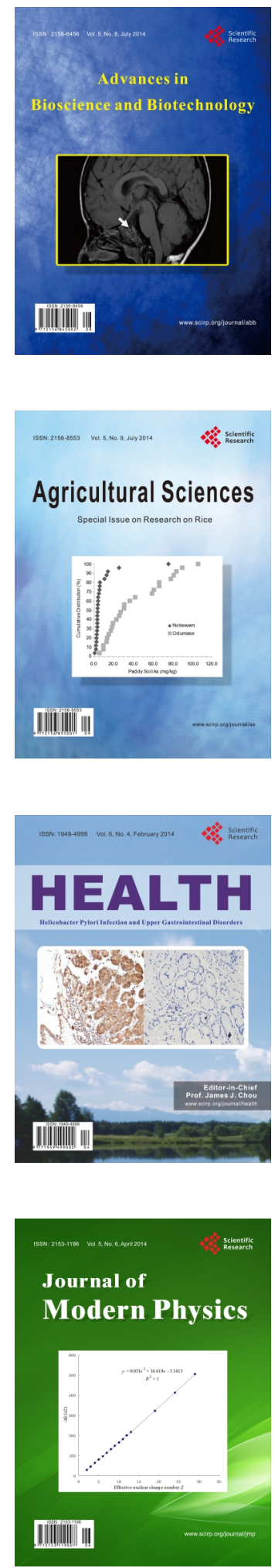
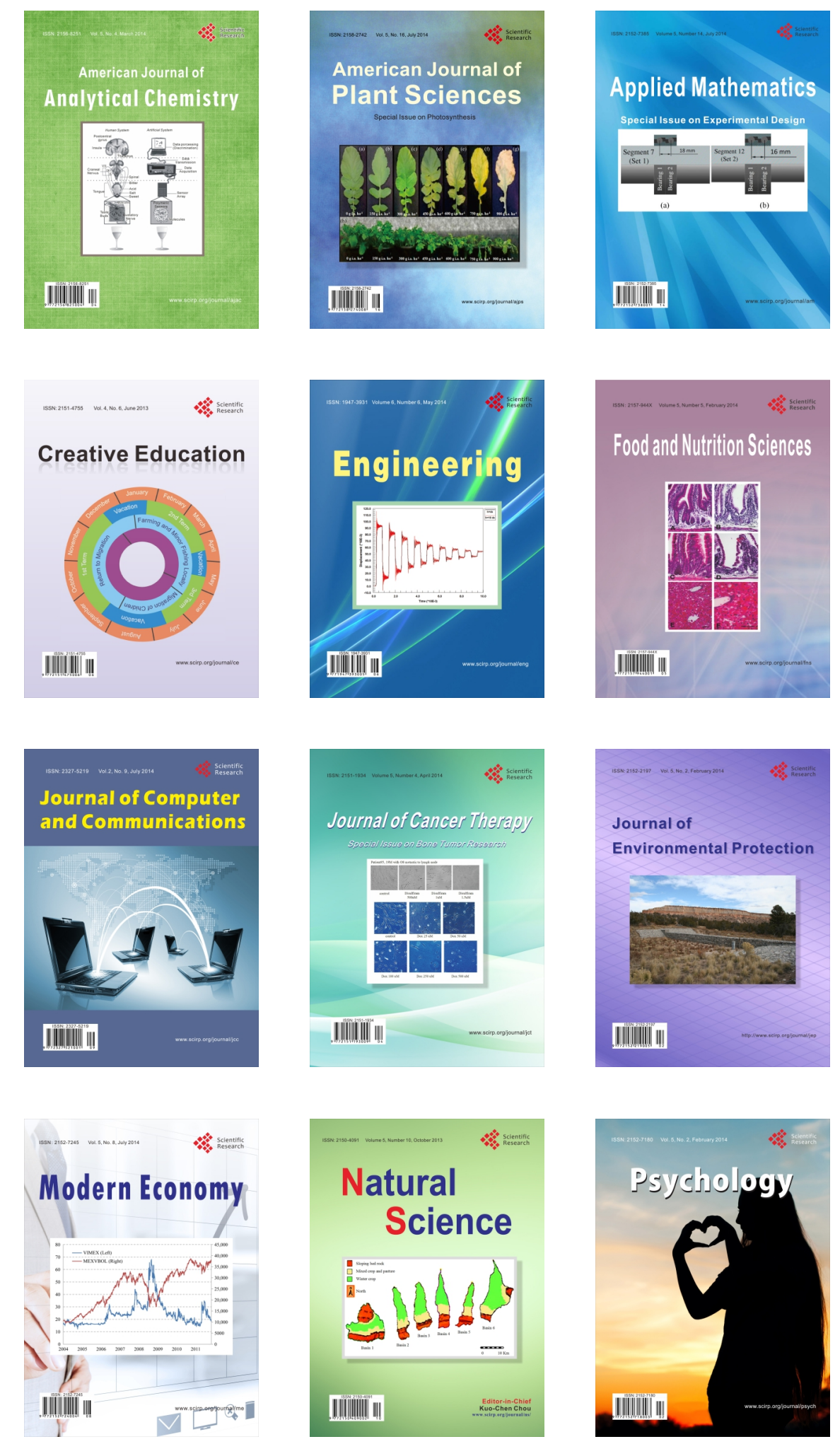